\title{
The Association Between the Integrated Health Post Activity and the Performance of Community Health Workers in Child Growth and Development Care Service in Karanganyar, Central Java
}

\author{
Lidia Ekiq Kurniavie'), Pawito²), Bhisma Murti') \\ 1)Masters Program in Public Health, Universitas Sebelas Maret, Surakarta \\ 2)Faculty of Social and Political Sciences, Universitas Sebelas Maret, Surakarta
}

\section{ABSTRACT}

Background: Active integrated health post is an integrated health post that conducts routine activities every month and conducts additional activities. There are $61.32 \%$ active integrated health posts in Indonesia. Early detection of growth and development is one of the tasks of the cadres at the integrated health post. The role of the integrated health post cadre that is not optimal will have direct and indirect effects on children. This study aimed to analyze the effect of the integrated health post activity on cadre performance in children under five in Karanganyar Regency.

Subjects and Method: This study used cross sectional design. This study was conducted in the integrated health post in Karanganyar from $\mathrm{Au}-$ gust-September 2019. There were 200 female college students involved as the sample of the study. They were selected by simple random sampling. The dependent variable was cadre performance of the integrated health post. The independent variables were cadre education, knowledge, attitude, employment status, years of service, training of children under five growth and development, facilities and infrastructure of the integrated health post, community support, and village government support. This study used questionnaires to collect the data. The data were analyzed by multiple logistic regression.

Results: Cadre performance in children under five growth and development in the integrated health post increased with high cadre education $(\mathrm{OR}=3.04 ; 95 \% \mathrm{CI}=1.24$ to $7.47 ; \mathrm{p}=0.015)$, cadres who worked at home $(\mathrm{OR}=3.66 ; 95 \% \mathrm{CI}=1.57$ to 8.50; $\mathrm{p}=0.003)$, high knowledge $(\mathrm{OR}=4.11 ; 95 \%$ $\mathrm{CI}=1.79$ to $9.42 ; \mathrm{p}=0.001)$, good attitude $(\mathrm{OR}=$ $3.31 ; 95 \% \mathrm{CI}=1.31$ to $8.38 ; \mathrm{p}=0.011)$, participation in growth and development training by $\geq 2$ times $(\mathrm{OR}=3.36 ; 95 \% \mathrm{CI}=1.49$ to $7.60 ; \mathrm{p}=0.004)$, length of service of the cadres $\geq 10$ years $(\mathrm{OR}=$ 3.21; $95 \% \mathrm{CI}=1.39$ to $7.43 ; \mathrm{p}=0.006$ ), complete facilities and infrastructure of the integrated health post $(\mathrm{OR}=4.17 ; 95 \% \mathrm{CI}=1.74$ to $9.99 ; \mathrm{p}=$ o.001), strong community support (OR=2.99; $95 \% \mathrm{CI}=1.26$ to $7.10 ; \mathrm{p}=0.013$ ), and high village government support $(\mathrm{OR}=2.76 ; 95 \% \mathrm{CI}=1.17 \mathrm{up}$ to $6.51 ; \mathrm{p}=0.020$ ).

Conclusion: Cadre performance in children under five growth and development is affected by cadre education, cadre occupation, cadre knowledge, cadre attitude, training of growth and development, length of service, facilities and infrastructure of the integrated health post, community support, and village government support.

Keywords: cadre performance, integrated health post activity, growth and development, children under five

\section{Correspondence:}

Lidia Ekiq Kurniavie. Masters Program in Public Health, Universitas Sebelas Maret. Jl. Ir. Sutami 36A, Surakarta 57126, Central Java. Email: ekiqlkv@gmail.com. Mobile: +6285852540575

Cite this as:

Kurniavie LE, Pawito, Murti B (2020). The association between the integrated health post activity and the performance of community health workers in child growth and development care service in Karanganyar, Central Java. J Health Policy Manage. 5(1): 48-6o. https://doi.org/10.26911/thejhpm.2020.05.01.05 Journal of Health Policy and Management is licensed under a Creative Commons Attribution-Non Commercial-Share Alike 4.o International License. 
Kurniavie et al./ The Association Between the Integrated Health Post Activity and the Performance

\section{BACKGROUND}

Integrated health post activity is an activity that is managed and organized from, by, for the community in the implementation of health development, in order to empower and facilitate the access to basic health services; it aims to accelerate the reduction in maternal and infant mortality (Khoirunisa et al., 2019).

The success of activities in integrated health post is the hard work of the cadres in managing integrated health post in their regions. One of the tasks of the cadre in integrated health post in the field of child health is conducting early detection on child growth and development (Ministry of Health, 2010). The assessment of children's growth and development does not functionate only as a medium of evaluating the health and nutritional status of children, but also provides a measure of the health inequalities faced by the community (de Onis, 2017).

The role of the integrated health post cadre that is not optimal will have direct and indirect effects on children. The direct effect for children is the children's health is not monitored due to the poor monitoring of growth and development. The indirect effect is the implementation of growth and development monitoring at integrated health post is inappropriate. Another effect for the family is the follow-up given to the child becomes inappropriate if the information received is unclear (LeFevre et al., 2015).

The implementation of the integrated health post activity will not run if the cadre performance is not good. As a result, the nutritional status of children under five cannot be clearly detected. This will directly affect the success of the integrated health post program in monitoring the children's growth and development. Several factors that can affect cadre performance are age, education, occupation, incentive, tenure, training, knowledge, attitude, facilities, community support, local government support, and others (Geldsetzer et al., 2017; Thakur et al., 2017).

\section{SUBJECTS AND METHOD}

\section{Study Design}

This study was an analytic observational study by using cross sectional design. This study was conducted in the integrated health post in Karanganyar from August-September 2019.

\section{Population and Sample}

The population of the study was cadre of the integrated health post in the integrated health post in Karanganyar. There were 200 subjects of the study involved as the sample of the study. They were selected by simple random sampling.

\section{Study Variables}

The dependent variable was cadre performance. The independent variables were cadre educational level, knowledge, attitude, employment status, years of service, training, facilities and infrastructure of the integrated health post, community support, and village government support.

4. Operational Definition of Variables Cadre educational level was the formal education completed by the cadre. This study used questionnaires as the measurement instrument. This study used categorical data scale. The data was converted into a dichotomy to facilitate analysis.

Cadre knowledge was measured by knowing the knowledge level of the cadre about the fulfillment of balanced nutrition and nutritional status in children under five. This study used questionnaires as the measurement instrument. This study used continuous data scale. The data was converted into a dichotomy.

Cadre attitude was the tendency to respond, assess, or express well during the process of monitoring the growth and development of children under five in the integrated health post. This study used questionnaires 
Kurniavie et al./ The Association Between the Integrated Health Post Activity and the Performance

as the measurement instrument. This study used continuous data scale. The data was converted into a dichotomy to facilitate analysis.

Cadre employment status was the cadre activities who worked to earn income besides cadre. This study used questionnaires as the measurement instrument. This study used categorical data scale. The data was converted into a dichotomy to facilitate analysis.

Cadre years of service was the time span of the cadres in carrying out their duties as part of activities in the integrated health post. This study used questionnaires as the measurement instrument. This study used continuous data scale. The data was converted into a dichotomy to facilitate analysis.

Training of children under five growth and development was the activity that was followed by cadres to increase knowledge and skills about monitoring the growth and development in children under five. This study used questionnaires as the measurement instrument. This study used continuous data scale. The data was converted into a dichotomy.

Facilities and infrastructure of Integrated Health Post was the facilities provided to support the implementation of activities in the integrated health post. This study used questionnaires as the measurement instrument. This study used continuous data scale. The data was converted into a dichotomy to facilitate analysis.

Community support was the process where the individuals, families, and community generally contributed to monitor the growth and development of children under five through their participation in the integrated health post. This study used questionnaires as the measurement instrument. This study used continuous data scale. The data was converted into dichotomous.

Village government support was support in the form of moral support, assistance, funds, and infrastructure. This study used questionnaires as the measurement instrument. This study used continuous data scale. The data was converted into a dichotomy to facilitate analysis.

\section{Data Analysis}

Univariate analysis was used to describe each dependent and independent variable. The data were categorized according to the data types. They were put in the tabel of frequency distribution. Bivariate analysis was used to determine the association between education, occupation, knowledge, attitude, training, years of service, facilities and infrastructure, community support, and village government support and cadre performance. They were measured by the chi-square test. Multivariate analysis explained the effects of education, occupation, knowledge, attitude, training, years of service, facilities and infrastructure, community support, and village government support on cadre performance. They were analyzed by multiple logistic regression. Univariate, bivariate, and multivariate analysis used the Stata 13 program.

\section{Research Ethic}

Reserch ethics consisted of informed consent form, anonymity, confidentiality, and ethical clearance. Ethical clearance in this study came from the Health Research Ethics Committee of Dr. Moewardi Hospital, Surakarta, Number: 1026/VIII/HREC/2019.

RESULTS
1. The Characteristics of the Sample
Table 1 shows that the majority of respon-
dents aged < 47 years; they were 103 people
$(51.50 \%)$. The last education of the majority
of respondents was senior high school; they
were 119 people ( $59.50 \%)$. The highest fre-
quency of cadres occupation was cadres who
worked outside; they were 112 people
(56.00\%).


Kurniavie et al./ The Association Between the Integrated Health Post Activity and the Performance

\section{Univariate Analysis}

Based on table 2, the measurement on the variable of knowledge showed that the mean and SD values were $13.74 \pm 1.34$ with the lowest value by 12 and the highest value by 17. The variable of attitude showed that the mean and SD values were $17.72 \pm 1.68$ with the lowest value by 14 and the highest value by 21. The variable of facilities and infrastructure of integrated health post showed that the mean and SD values were 6.70 \pm 0.94 with the lowest value by 5 and the highest value by 8 . The variable of community support indicated that the mean and SD values were $16.89 \pm 2.39$ with the lowest value by 13 and the highest value by 22 . The variable of village government support showed that the mean and SD values were $17.87 \pm 2.66$ with the lowest value by 12 and the highest value by 23 . The variable of cadre performance showed that the mean and SD values were $7.7 \pm 1.63$ with the lowest value by 6 and the highest value by 11 .

Table 1. The characteristic of the study subjects

\begin{tabular}{llcc}
\hline \multicolumn{1}{c}{ Variable } & \multicolumn{1}{c}{ Criteria } & Frequency (n) & Percentage (\%) \\
\hline Age of Cadre & $<47$ years & 103 & 51.50 \\
& $\geq 47$ years & 97 & 48.50 \\
Cadre Education & Elementary School & 4 & 2.00 \\
& Junior High School & 70 & 35.00 \\
& Senior High School & 119 & 59.50 \\
& College & 7 & 3.50 \\
Cadre Occupation & Working outside & 112 & 56.00 \\
& Working at home & 88 & 44.00 \\
\hline
\end{tabular}

Table 2. The univariate analysis (continuous data)

\begin{tabular}{llllll}
\hline \multicolumn{1}{c}{ Variable } & n & Mean & SD & Min. & Max. \\
\hline Knowledge & 200 & 13.74 & 1.34 & 12 & 17 \\
Attitude & 200 & 17.72 & 1.68 & 14 & 21 \\
Years of service & 200 & 11.02 & 3.33 & 6 & 21 \\
Training of children under five & 200 & 1.58 & 0.75 & 0 & 3 \\
growth and development & & & & & 8 \\
Facilities and Infrastructure & 200 & 6.70 & 0.94 & 5 & 8 \\
Community Support & 200 & 16.89 & 2.39 & 13 & 22 \\
Village Government Support & 200 & 17.87 & 2.66 & 12 & 23 \\
Cadre Performance & 200 & 7.70 & 1.63 & 6 & 11 \\
\hline
\end{tabular}

Table 3 presents data of univariate analysis (dichotomous data) from 200 study subjects. There were 126 people $(63.00 \%)$ who had $\geq$ SHS and 74 people (37.00\%) who had $<$ SHS. There were 112 cadres $(56.00 \%)$ who worked outside and 88 cadres (44.00\%) who worked at home.

There were 90 respondents (45.00\%) who had low knowledge and 110 people (55.00\%) who had high knowledge. There were 64 cadres $(32.00 \%)$ who had poor attitude and 136 cadres (68.00\%) who had good attitude. There were 102 cadres $(51.00$ \%) attended the growth and development training $\geq 2$ times and 98 cadres (49.00\%) attended the growth and development training $<2$ times.

There were 110 people (55.00 \%) who have just worked as cadres and 90 people (45.00\%) who had been working as cadres for a long time. There were 125 integrated health posts $(62.50 \%)$ had complete facilities 
Kurniavie et al./ The Association Between the Integrated Health Post Activity and the Performance

and infrastructure and 75 integrated health posts (37.50\%) had incomplete facilities and infrastructure.

The percentage of the integrated health posts that had weak community support was $57 \%$. The integrated health post activity that received strong village government support was $68 \%$. There were 101 cadres (50.50\%) who had good performance and 99 cadres (49.50\%) who had poor performance.

\section{Bivariate Analysis}

The bivariate analysis in this study aimed to explain the association between one independent variable (education, knowledge, attitude, training, years of service, occupation, facilities and infrastructure of integrated health post, community support, and village government support) and one dependent variable (cadre performance). The results of the bivariate analysis can be seen in table 4 .

Table 3. Univariate analysis (dichotomous data)

\begin{tabular}{llll}
\hline \multicolumn{1}{c}{ Variable } & \multicolumn{1}{c}{ Criteria } & Frequency (n) & Percentage (\%) \\
\hline Education & S SHS & 74 & 37.00 \\
Occupation & $\geq$ SHS & 126 & 63.00 \\
& Working outside & 112 & 56.00 \\
Knowledge & Working at home & 88 & 44.00 \\
& Low & 90 & 45.00 \\
Attitude & High & 110 & 55.00 \\
\multirow{3}{*}{ Training of Child Growth and } & Poor & 64 & 32.00 \\
Development & Good & 136 & 68.00 \\
Years of service & $\geq 2$ times & 98 & 49.00 \\
\multirow{3}{*}{ Facilities and Infrastructure } & 102 & 51.00 \\
Community Support & incomplete & 110 & 55.00 \\
& complete & 90 & 45.00 \\
Village Government Support & Weak & 125 & 37.50 \\
& Strong & 86 & 62.50 \\
Cadre Performance & Strong & 64 & 57.00 \\
& Poor & 136 & 43.00 \\
& Good & 99 & 32.00 \\
\hline
\end{tabular}

There was an effect of cadre education on cadre performance in children under five growth and development. The cadres who had $\geq$ SHS had better performance compared to the cadres who had $<$ SHS. The cadres who had $\geq$ SHS had 2.48 times possibility to have good performance compared to the respondents who had $<$ SHS.

There was an effect of cadre occupation on cadre performance in children under five growth and development. The cadres who worked outside the home (66.07\%) had lower performance compared to the cadres who worked at home. The cadres who worked at home had 4.91 times possibility to have good performance compared to the cadres who worked outside the home.

There was an effect of cadre knowledge on cadre performance in children under five growth and development. The cadres who had high knowledge (69.09\%) had better performance compared to the cadres who had low knowledge. The cadres who had high knowledge had 5.81 times possibility to have 
Kurniavie et al./ The Association Between the Integrated Health Post Activity and the Performance

good performance compared to the cadres who had low knowledge.

There was an effect of cadre attitude on cadre performance in children under five growth and development. The cadres who had positive attitude (60.29\%) had good performance compared to the cadres who had poor attitude. The cadres who had positive attitude had 3.60 times possibility to have good performance compared to the cadres who had negative attitude.

There was an effect of growth and development training on cadre performance in children under five growth and development. The cadres who participated in training $\geq 2$ times (70.59\%) had good performance com- pared to the cadres who participated in training $<2$ times. The cadres who participated in training $\geq 2$ times had 5.71 times possibility to have good performance compared to the cadres who participated in training $<2$ times.

There was an effect of years of service of the cadres on cadre performance in children under five growth and development. The cadres who worked $\geq 10$ years $(59.09 \%)$ had good performance compared to the cadres who worked $<10$ years. The cadres who worked $\geq 10$ years had 2.38 times possibility to have good performance compared to the cadres who worked $<10$ years $(O R=2.48$; $p=$ 0.003 .

Table 4. Bivariate Analysis

\begin{tabular}{|c|c|c|c|c|c|c|c|c|}
\hline \multirow{3}{*}{ Variable } & \multicolumn{4}{|c|}{ Cadre Performance } & \multirow{2}{*}{\multicolumn{2}{|c|}{ Total }} & \multirow{3}{*}{ OR } & \multirow{3}{*}{$\mathbf{p}$} \\
\hline & \multicolumn{2}{|c|}{ Poor } & \multicolumn{2}{|c|}{ Good } & & & & \\
\hline & $\mathbf{N}$ & $\%$ & $\mathbf{N}$ & $\%$ & $\mathbf{N}$ & $\%$ & & \\
\hline \multicolumn{9}{|l|}{ Education } \\
\hline$<$ SHS & 47 & 63.51 & 27 & 36.49 & 74 & 100 & \multirow[t]{2}{*}{2.48} & \multirow[t]{2}{*}{0.002} \\
\hline$\geq$ SHS & 52 & 41.27 & 74 & 58.73 & 126 & 100 & & \\
\hline \multicolumn{9}{|l|}{ Occupation } \\
\hline Working outside & 74 & 66.07 & 38 & 33.93 & 112 & 100 & \multirow[t]{2}{*}{4.91} & \multirow[t]{2}{*}{$<0.001$} \\
\hline Working at home & 25 & 28.41 & 63 & 71.59 & 88 & 100 & & \\
\hline \multicolumn{9}{|l|}{ Knowledge } \\
\hline Low & 65 & 72.22 & 25 & 27.78 & 90 & 100 & \multirow[t]{2}{*}{5.81} & \multirow[t]{2}{*}{$<0.001$} \\
\hline High & 34 & 30.91 & 76 & 69.09 & 110 & 100 & & \\
\hline \multicolumn{9}{|l|}{ Attitude } \\
\hline Negative & 45 & 70.31 & 19 & 29.69 & 64 & 100 & \multirow[t]{2}{*}{3.60} & \multirow[t]{2}{*}{$<0.001$} \\
\hline Positive & 54 & 39.71 & 82 & 60.29 & 136 & 100 & & \\
\hline \multicolumn{9}{|l|}{ Training } \\
\hline$<2$ times & 69 & 70.41 & 29 & 29.59 & 98 & 100 & \multirow[t]{2}{*}{5.71} & \multirow[t]{2}{*}{$<0.001$} \\
\hline $\begin{array}{l}\geq 2 \text { times } \\
\text { Years of Service }\end{array}$ & \multicolumn{6}{|c|}{ Years of Service } & & \\
\hline New & 65 & 59.09 & 45 & 40.91 & 110 & 100 & \multirow{2}{*}{2.38} & \multirow{2}{*}{0.003} \\
\hline Old & 34 & 37.78 & 56 & 62.22 & 90 & 100 & & \\
\hline \multirow{2}{*}{\multicolumn{9}{|c|}{$\begin{array}{l}\text { Facilities and } \\
\text { Infrastructure }\end{array}$}} \\
\hline & & & & & & & & \\
\hline Incomplete & 54 & 72.00 & 21 & 28.00 & 75 & 100 & \multirow[t]{2}{*}{4.57} & \multirow[t]{2}{*}{$<0.001$} \\
\hline Complete & 45 & 36.00 & 80 & 64.00 & 125 & 100 & & \\
\hline \multicolumn{9}{|c|}{ Community Support } \\
\hline Weak & 69 & 60.53 & 45 & 39.47 & 114 & 100 & \multirow[t]{2}{*}{2.86} & $<0.001$ \\
\hline Strong & 30 & 34.88 & 56 & 65.12 & 86 & 100 & & \\
\hline $\begin{array}{l}\text { Village GovernmeI } \\
\text { Sunnort }\end{array}$ & & & & & & & & \\
\hline Weak & 46 & 71.88 & 18 & 28.13 & 64 & 100 & 4.00 & $<0.001$ \\
\hline Strong & 53 & 38.97 & 83 & 61.03 & 136 & 100 & & \\
\hline
\end{tabular}


Kurniavie et al./ The Association Between the Integrated Health Post Activity and the Performance

There was an effect of facilities and infrastructure of the integrated health post on cadre performance in children under five growth and development. The complete facilities and infrastructure of the integrated health post (64.00\%) made the cadre performance good compared to the incomplete facilities and infrastructure. The complete facilities and infrastructure of the integrated health post had 4.57 times possibility to make the cadre performance good compared to the incomplete facilities and infrastructure.

There was an effect of community support on cadre performance in children under five growth and development. Strong community support $(60.53 \%)$ had good cadre performance. Strong community support had 2.86 times possibility to make the cadre performance good compared to the cadres who got weak community support.

There was an effect of village government support on cadre performance in child- ren under five growth and development. Strong village government support (61.03\%) had good cadre performance. Strong village government support had 4.00 times possibility to make the cadre performance good compared to the cadres who got weak village government support

\section{Multivariate Analysis}

Multivariate analysis used multilevel multiple logistic regression method. They were analyzed by using Stata 13. Multivariate analysis explained the effect of more than 1 independent variable on 1 dependent variable. Table 5 shows that cadre performance affected by cadre education, cadre occupation, cadre knowledge, cadre attitude, training of children under five growth and development, cadre years of service, facilities and infrastructure of integrated health post, community support, and village government support.

Table 5. The analysis of the multiple logistic regression of a number of variables with cadre performance

\begin{tabular}{|c|c|c|c|c|}
\hline \multirow{2}{*}{ Variable } & \multirow{2}{*}{$\mathbf{O R}$} & \multicolumn{2}{|c|}{ (95\%) CI } & \multirow{2}{*}{$\mathbf{p}$} \\
\hline & & Lower Limit & Upper Limit & \\
\hline Cadre education ( $\geq$ SHS) & 3.04 & 1.24 & 7.47 & 0.015 \\
\hline Cadre occupation (working at home) & 3.66 & 1.57 & 8.50 & 0.003 \\
\hline Cadre knowledge (high) & 4.11 & 1.79 & 9.41 & 0.001 \\
\hline Cadre attitude (positive) & $3 \cdot 31$ & 1.31 & 8.38 & 0.011 \\
\hline $\begin{array}{l}\text { Training of child growth and development } \\
\text { ( } \geq 2 \text { times) }\end{array}$ & $3 \cdot 36$ & 1.49 & 7.60 & 0.004 \\
\hline Years of service ( $\geq 10$ years) & 3.21 & 1.39 & 7.43 & 0.006 \\
\hline Facilities and infrastructure (complete) & 4.17 & 1.74 & 9.99 & 0.001 \\
\hline Community support (strong) & 2.99 & 1.26 & 7.10 & 0.013 \\
\hline Village government support (strong) & 2.76 & 1.17 & 6.51 & 0.020 \\
\hline \multicolumn{5}{|l|}{$\mathrm{N}$ Observation $=200$} \\
\hline \multicolumn{5}{|l|}{ Log Likelihood= $=-76.95$} \\
\hline \multicolumn{5}{|l|}{$\mathrm{R}^{2}=0.44$} \\
\hline $\mathrm{p}<0.001$ & & & & \\
\hline
\end{tabular}


Kurniavie et al./ The Association Between the Integrated Health Post Activity and the Performance

The cadres performance improved with cadre education $\geq \mathrm{SHS}(\mathrm{OR}=3.04 ; 95 \% \mathrm{CI}=1.24$ to 7.47; $\mathrm{p}=0.015)$, cadres who worked at home $(\mathrm{OR}=3.66 ; 95 \% \mathrm{CI}=1.57$ to $8.50 ; \mathrm{p}=0.003)$, cadre who had high knowledge $(\mathrm{OR}=4.11$; $95 \% \mathrm{CI}=1.79$ to $9.41 ; \mathrm{p}=0.001)$, cadres positive attitude $(\mathrm{OR}=3.31 ; 95 \% \mathrm{CI}=1.31$ to 8.38 ; $\mathrm{p}=0.011)$, training $\geq 2$ times $(\mathrm{OR}=3.36$; $95 \% \mathrm{CI}=1.49$ to $7.60 ; \mathrm{p}=0.004)$, years of service $\geq 10$ years $(\mathrm{OR}=3.21 ; 95 \% \mathrm{CI}=1.39$ to $7.43 ; \mathrm{p}=0.006)$, complete facilities and infrastructure of the integrated health post (OR= 4.17; $95 \% \mathrm{CI}=1.74$ to $9.99 ; \mathrm{p}=0.001)$, strong community support $(\mathrm{OR}=2.99 ; 95 \% \mathrm{CI}=1.26$ to $7.10 ; \mathrm{p}=0.013$ ), and strong village government support $(\mathrm{OR}=2.76$; $95 \% \mathrm{CI}=1.17$ to 6.51 ; $\mathrm{p}=0.020$ ).

\section{DISCUSSION}

\section{The Effect of Cadre Education on Cadre Performance}

The result showed that there was a positive effect of cadre education $(\mathrm{OR}=3.04$; $95 \% \mathrm{CI}=$ 1.24 to $7.47 ; \mathrm{p}=0.015$ ) on cadre performance. The cadres who had $\geq$ SHS had logodd to have good performance by 3.04 units higher than the cadres who had $<$ SHS.

High educational status was a positive factor that was significantly related to cadre performance. Higher education level would contribute to the high level of health knowledge, an indicator of performance in this study. In addition, cadres with higher educational status would easily understand how to write and submit their monthly reports (Ma et al., 2019).

This study is in accordance with a study conducted by Westgard et al. (2018) that education played a large role in productivity. The higher the education level, the better the level of productivity in carrying out a job. Another similar study also suggested that high level of education produced good performance (Burhan et al., 2019).

\section{The Effect of Cadre Occupation on Cadre Performance}

The result showed that there was a positive effect of cadre employment status $(\mathrm{OR}=3.66$; 95\% CI= 1.57 to $8.50 ; \mathrm{p}=0.003$ ) on cadre performance of children under five growth and development in integrated health post. The cadres who worked at home had logodd to have good performance by 3.66 units higher than the cadres who worked outside the home.

This study is in line with a study conducted by Kok et al. (2015) that most of the cadres in Bangladesh who had good performance were cadres who did not face the problem of more responsibilities in the household, such as breadwinners in the family. Cadres still need other occupation to fulfill their financial needs, so there is little time to carry out cadre tasks (Asweto et al., 2016).

The dilemma in the job of community based health service is the appropriate balance of duties and responsibilities for unpaid voluntary work versus paid work. The benefits they receive are low, whereas the living cost and the amount of time they give to public health work increases (Kelly et al., 2018).

\section{The Effect of Cadre Knowledge on Cadre Performance}

The result of the study showed that there was positive effect of cadre knowledge $(\mathrm{OR}=4.11$; CI $95 \%=1.79$ to $9.42 ; \mathrm{p}=0.001$ ) on the cadre performance of children under five growth and development in integrated health post. The cadres who had high knowledge had logodd to have good performance by 4.11 units higher than the cadres who had low knowledge.

Good knowledge of the duties and responsibilities within an organization tends to improve the quality of work. The knowledge that increases or decreases will affect the understanding, the way of thinking, and the analysis of things; as a result, it gives a 
Kurniavie et al./ The Association Between the Integrated Health Post Activity and the Performance

different perception of the observed object which will ultimately change a person's behavior (Sahanggamu et al., 2017).

The high level of cadre knowledge makes good cadre performance. In addition, it has an effect on the implementation of the program in integrated health post. The better or higher the knowledge of cadres, the better the active level in the implementation process of the integrated health post activity. Based on the result of the study and opinion expressed, there is an association between knowledge and cadre performance in the implementation of integrated healh post activity (Tsolekile et al., 2018).

\section{The Effect of Cadre Attitude on Cadre Performance}

The result of the study showed that there was positive effect of cadre attitude $(\mathrm{OR}=4.11$; $95 \% \mathrm{CI}=1.79$ to $9.42 ; \mathrm{p}=0.001$ ) on the cadre performance of children under five growth and development in integrated health post. The cadres who had positive attitude had logodd to have good performance by 3.31 units higher than the cadres who had negative attitude.

Attitude is a general evaluation carried out by humans on themselves, others, objects, or problems. It is certain regularities in terms of feelings, thoughts and actions. Based on the result of a study at Sulau community healh center, South Bengkulu, cadre attitude had a positive effect and increased the cadre performance by 9.97 times better (Burhan et al., 2019).

Based on a study conducted by Tlale et al. (2015) in Botswana, knowledge, attitude, and practice affected performance of health service workers. A person's negative attitude can be caused by the lack of competence of the party in understanding his duties. Attitude and value are the things that give power to encourage individuals to act in order to achieve their goals.

\section{The effect of training of childre under five growth and development on cadre performance}

The result of the study showed that there was positive effect of the number of children under five growth and development training followed by the cadres $(\mathrm{OR}=3.36 ; 95 \% \mathrm{CI}=$ 1.49 to $7.60 ; \mathrm{p}=0.004$ ) on the cadre performance of children under five growth and development in integrated health post. The cadres who participated in growth and development training $\geq 2$ times had logodd to have good performance by 3.36 units higher than the cadres who participated in growth and development training $<2$ times.

Training aims to provide additional knowledge. It also expands knowledge related to how to provide the best service for health through improved performance. However, for the assessment of long-term effects on performance, the evaluation of management and performance result are carried out to assess the effectiveness of training (Wardhani et al., 2019).

Based on the statistical test of the study conducted by Aftab et al. (2018), frequency of attendance affected cadres' performance in integrated health post activities in Pakistan. Training is a part of education concerns the learning process to acquire and improve skills outside existing education system in a short period of time. The method of practice is more prioritized than theory. Training aims to teach a number of skills, knowledge, and attitude needed by employees to improve their ability to carry out their duties.

\section{The effect of years of service on cadre performance}

The result of the study showed that there was positive effect of cadre years of service $(\mathrm{OR}=$ 3.21; $95 \% \mathrm{CI}=1.39$ to $7.43 ; \mathrm{p}=0.006$ ) on the cadre performance of children under five growth and development in integrated health post. The cadres who had been working as cadres for a long time had logodd to have 
Kurniavie et al./ The Association Between the Integrated Health Post Activity and the Performance

good performance by 3.21 units higher than the cadres who have just worked as cadres.

Cadres that have long work experience have more opportunities to receive effective training, supervision, and any incentives. In addition, they can build confidential relationships with the community. All of these factors will positively affect their performance. Therefore, length of service is one of the biggest concerns in maintaining effective public health activities, with influencing factors that have been reported by various other studies (Kawakatsu et al., 2015).

The result of this study is in line with a study conducted by Kok et al. (2015) that many years of experience as a cadre were associated with the use of appropriate work aids, client satisfaction, and client empowerment in Kenya; therefore, their performance was better than before. Cadres with long years of service may have more experience than new cadres.

\section{The effect of facilities and infra- structure of integrated health post on cadre performance}

The result of the study showed that there was positive effect of the availability of the facilities and infrastructure of the integrated health post $(\mathrm{OR}=4.17 ; 95 \% \mathrm{CI}=1.74$ to 9.99 ; $\mathrm{p}=0.001$ ) on the cadre performance of children under five growth and development in integrated health post. The integrated health post that had complete facilities and infrastructure had logodd to have good performance by 4.17 units higher than the integrated health post that had incomplete facilities and infrastructure.

The availability of medical devices affects the performance of health workers who are high-powered. Health workers feel more proud and easier to do their duties if they are supported by good facilities (Pratama et al., 2018).

Facility is the potential value possessed by certain materials or elements in life. Re- sources are not always physical, but also nonphysical (intangible). Resources can also be anything that allows an individual to get satisfaction. Facilities are the infrastructure to do or make things easier. Resources can also be considered as tools (Ernawati, Sulaeman and Indarto, 2018).

\section{The effect of community support on cadre performance}

The result of the study showed that there was positive effect of community support (OR= 2.99; $95 \% \mathrm{CI}=1.26$ to $7.10 ; \mathrm{p}=0.013$ ) on the cadre performance of children under five growth and development in integrated health post. The cadres with strong community support had logodd to have good performance by 2.99 units higher than the

Support, response, and community participation affect the cadres' performance in integrated health post. This is related to the length of time the subject being a cadre. The longer he becomes a cadre, the more popular he is in the community. The cadre will get more respect from the community. Therefore, many people will participate in integrated health post activities, both in decision making and routine activities (Phiri et al., 2017).

\section{The effect of village government support on cadre performance}

The result of the study showed that there was positive effect of cadre education $(\mathrm{OR}=2.76$; $95 \% \mathrm{CI}=1.17$ to $6.51 ; \mathrm{p}=0.020$ ) on the cadre performance of children under five growth and development in integrated health post. The cadres with strong village government support had logodd to have good performance by 2.76 units higher than the cadres with weak village government support.

Leader support affects the performance of employees such as cadres. The role of the leader can be the ideas and interests, relationships and power, values and norms of decision makers regarding health services in the region (Ludwick et al., 2018). 
Kurniavie et al./ The Association Between the Integrated Health Post Activity and the Performance

Government support is very closely related to decision or policy made in a region. This policy can affect the cadre performance because it is associated with government support regarding procurement of fund, facilities and infrastructure, road access, monitoring, procurement of training, and so on (Leon et al., 2015).

\section{AUTHOR CONTRIBUTION}

Lidia Ekiq Kurniavie as the main researcher who played a role in coordinating the study, conducting all stages of study, and completing the study scripts. Pawito played a role in developing ideas, study design, and the hypotheses of the study. Bhisma Murti played a role in developing framework of the study, processing the data of the study, representing the results of the analysis, and preparing the study scripts.

\section{CONFLICT OF INTEREST}

There was no conflict of interest in this study.

FUNDING AND SPONSORSHIP

This study used personal funds from the main authors.

\section{ACKNOWLEDGEMENT}

We give the best gratitude to the community health center in Karanganyar Regency for allowing us to conduct this study. We also give the gratitude to all cadres who have been willing and cooperative to become the respondents of the study

\section{REFERENCE}

Aftab W, Rabbani F, Sangrasi K, Perveen S, Zahidie A, Qazi SA (2018). Improving community health worker performance through supportive supervision: a randomised controlled implementation trial in Pakistan. Int J Paediatrics, 107: 63-71. https://doi.org/10.1111/apa.14282.
Asweto CO, Alzain MA, Andrea S, Alexander $\mathrm{R}$, Wang W (2016). Integration of community health workers into health systems in developing countries: Opportunities and challenges. Fam Med Community Health, 4: 37-45. https://doi.org/10.15212/FMCH.2016.0102.

Burhan R, Marsofely RL, Suryanti (2019). Factors related to the performance of cadre in the implementation of toddler posyandu at the working area of Puskesmas Sulau in South Bengkulu Regency. Proceedings of the 1st International Conference on Inter-Professional Health Collaboration. https://doi.org/10.2991/icihc18.2019.56.

de Onis M (2017). Child growth and development. In Nutrition and health in a developing world. 3(87): 119-141. https://doi.org/10.1007/978-3-31943739-2_6.

Ernawati E, Sulaeman ES, Indarto D (2018). Associations of self-efficacy, family support, peer support, and posyandu facility, with mother's visit to posyandu in Karanganyar, Central Java. J Matern Child Health, 03(03): 233-241. https://doi.org/10.26911/thejmch.2018.03.03 .08 .

Geldsetzer P, De Neve JW, Boudreaux C, Bärnighausen T, Bossert TJ (2017). Improving the performance of community health workers in Swaziland: findings from a qualitative study. Hum Res Health, 15(1): 68. https://doi.org/10.1186/s12960-017-0236-x.

Kawakatsu Y, Sugishita T, Tsutsui J, Oruenjo $\mathrm{K}$, Wakhule S, Kibosia K, Honda S, et al. (2015). Individual and contextual factors associated with community health workers' performance in Nyanza Province, Kenya: A multilevel analysis. BMC Health Serv Res, 15(1): 442. https://doi.org/10.1186/s12913-015-1117-4. Kelly A, Mitra S, Elung'at J, Songok J, 
Kurniavie et al./ The Association Between the Integrated Health Post Activity and the Performance

Jackson S, Christoffersen-Deb A (2018). Can the financial burden of being a community health volunteer in western Kenya exacerbate poverty? Health Promotion Intl. 1-9. https://doi.org/10.1093/heapro/day110.

Khoirunisa E, Karsidi R, Yusuf M (2019). Role of posyandu as primary health care services in implementing early detection and intervention for autistic children in Indonesia. Int $\mathrm{J}$ Multicultural and Multireligious Understanding, 6(1): 101-109. Retrieved from https://ijmmu.com/index.php/ijmmu/article/v iew/511/358.

Kok MC, Dieleman M, Taegtmeyer M, Broerse JEW, Kane SS, Ormel H, De Koning KAM, et al. (2015, November 1). Which intervention design factors influence performance of community health workers in low- and middleincome countries? A systematic review. Health Policy and Planning, 30: 12071227. https://doi.org/10.1093/heapol/czu126.

Kok MC, Kane SS, Tulloch O, Ormel H, Theobald S, Dieleman M, de Koning KAM, et al. (2015). How does context influence performance of community health workers in low- and middleincome countries? Evidence from the literature. Health Res Policy Sys, 13(1). https://doi.org/10.1186/s12961-015o001-3.

LeFevre AE, Mpembeni R, Chitama D, George AS, Mohan D, Urassa DP, Winch PJ, et al. (2015). Profile, knowledge, and work patterns of a cadre of maternal, newborn, and child health CHWs focusing on preventive and promotive services in Morogoro Region, Tanzania. Hum Res Health, 13(1): 98. https://doi.org/10.1186/s12960-015-0086-3.

Leon N, Sanders D, Van Damme W, Besada
D, Daviaud E, Oliphant NP, Doherty T, et al. (2015). The role of "hidden" community volunteers in communitybased health service delivery platforms: examples from sub-Saharan Africa. Global Health Action, 8 (27214). https://doi.org/10.3402/gha.v8.27214

Ludwick T, Turyakira E, Kyomuhangi T, Manalili K, Robinson S, Brenner JL (2018). Supportive supervision and constructive relationships with healthcare workers support CHW performance: Use of a qualitative framework to evaluate $\mathrm{CHW}$ programming in Uganda. Hum Res Health, 16(1): 1-8. https://doi.org/10.1186/s12960-0180272-1.

Ma Y, Sudfeld CR, Kim H, Lee J, Cho Y, Awoonor-Williams JK, Cha S, et al. (2019). Evaluating the impact of community health volunteer home visits on child diarrhea and fever in the Volta Region, Ghana: A cluster-randomized controlled trial. PLOS Medicine, 16(6): e1002830. https://doi.org/10.1371/journal.pmed.1002830.

Ministry of Health. (2010). Pelayanan stimulasi deteksi intervensi dini tumbuh kembang anak. Kemenkes RI, 2-3. Retrieved from http://www.depkes.go.id/article/view/1137/pelayanan-stimulasi-deteksi-intervensi-dini-tumbuh-kembang-anak. \html.

Phiri SC, Prust ML, Chibawe CP, Misapa R, van den Broek JW, Wilmink N (2017). An exploration of facilitators and challenges in the scale-up of a national, public sector community health worker cadre in Zambia: a qualitative study. Hum Resour Health, 15(1): 40. https://doi.org/10.1186/s12960-0170214-3.

Pratama TWY, Tamtomo D, Sulaeman ES (2018). Factors Associated with the Completeness of Inpatient Medical Record Filling in Dr. R Sosodoro Djati- 
Kurniavie et al./ The Association Between the Integrated Health Post Activity and the Performance

koesoemo, Bojonegoro, East Java. J Health Policy Manag, 3(1): 1-10. https://doi.org/10.26911/thejhpm.2018.03.01.01.

Sahanggamu PD, Purnomosari L, Dillon D (2017). Information exposure and growth monitoring favour child nutrition in rural Indonesia. Asia Pac J Clin Nutr, 26(2): 313-316. https://doi.org/10.6133/APJCN.012016.09.

Thakur H, Garcia DM, Kuule Y, Dobson AE, Woldeyohannes D, Zolfo M, Wilkinson $\mathrm{E}$, et al. (2017). Community health volunteers in primary healthcare in Rural Uganda: factors influencing performance. Frontiers Public Health, 5, 62. https://doi.org/10.3389/fpubh.2017.00062.

Tlale LB, Masupe T, Molefi M, Tshikuka JG (2015). KAP study on TB contact tracing Knowledge, Attitudes and Practices of health care workers' towards tuberculosis contact tracing in a $\mathrm{TB} /-$ HIV Prevalent setting. Int J Int Med Res, 2(3). Retrieved from https://- pdfs.semanticscholar.org/8c25/o7be16 8624f98fob4-1b963158b6ocdbf5c67.pdf.

Tsolekile LP, Schneider H, Puoane T (2018). The roles, training and knowledge of community health workers about diabetes and hypertension in Khayelitsha, Cape Town. Curationis, 41(1). https://doi.org/10.4102/curationis.v41i1.1815 .

Wardhani ATLK, Tamtomo D, Budihastuti UR (2019). Multilevel analysis on the contextual effect of community health center on health workers performance. J Health Policy Manag, 4(3): 182-194. https://doi.org/10.26911/thejhpm.2019.04.03.06.

Westgard C, Naraine R, Villacorta DMP (2018). Performance evaluation of community health workers: case study in the Amazon of Peru. J Community Health, 43(5): 908-919. https://doi.org/10.1007/s10900-018-0503-3. 